\title{
PENYELESAIAN PEMBAGIAN WARISAN DI KECAMATAN SIMPANG ULIM DALAM PERSPEKTIF HUKUM ISLAM DAN HUKUM ADAT
}

\author{
Muhammad Nasir \\ Institut Agama Islam Negeri Langsa \\ muhammadnasir@iainlangsa.ac.id \\ Khalidah \\ Institut Agama Islam Negeri Langsa \\ Khalidahbda@yahoo.co.id
}

\begin{abstract}
In Acehnese society, the implementation of inheritance law is influenced by customary law living in the community, the heirs are in accordance with what has been stipulated in faraid law, but in the distribution of wealth sometimes it does not follow faraid law, but according to mutual agreement. Determination of inheritance in the Acehnese community in Simpang Ulim District, whose majority Muslim community, in terms of handling inheritance more depends on the heirs, this method is called the familial way, and can run well without conflict, for example the parties agree to divide the amount of the expert's assets. the inheritance for boys is equal to that given to girls. This research is a field study with a qualitative approach. The primary sources in this study were informants from the Simpang Ulim Community whose data were taken by random sampling. The results of the study concluded two things; First, the mechanism for implementing the distribution of the inheritance of the Acehnese people in Simpang Ulim District is carried out in two ways, firstly by purely Islamic law, and by means of kinship (custom). The reason for the implementation of the family system is because the majority of people do not understand the law of inheritance in totality in Islam. Second, the application of Islamic inheritance law to the implementation of inheritance law in the Acehnese people in Simpang Ulim District is complementary and side by side with customary law. On this occasion, the heirs will ask for guidance from religious leaders by kinship consensus.
\end{abstract}

Keywords: Dakwah, Family, Character Building, Islamic Perspective.

\begin{abstract}
Abstrak
Dalam masyarakat Aceh, pelaksanaan hukum waris dipengaruhi oleh hukum adat yang hidup di masyarakat, ahli warisnya sesuai dengan yang telah ditetapkan dalam hukum faraid, tetapi pada pembagian hartanya terkadang tidak mengikuti hukum faraid, tetapi sesuai kesepakatan bersama. Penetapan kewarisan pada masyarakat Aceh di Kecamatan Simpang Ulim yang masyarakatnya mayoritas
\end{abstract}


beragama Islam, dalam hal penanganan warisan lebih banyak tergantung kepada ahli warisnya, cara tersebut disebut dengan cara kekeluargaan, dan dapat berjalan dengan baik tanpa adanya konflik, misalnya para pihak bersepakat membagi jumlah harta ahli waris anak laki-laki sama besar dengan yang diberikan untuk anak perempuan. Penelitian ini adalah kajian lapangan dengan pendekatan kualitatif. Sumber primer dalam penelitian ini adalah informan dari Masyarakat Simpang Ulim yang diambil datanya secara random sampling. Hasil penelitian menyimpulkan dua hal; Pertama, mekanisme pelaksanaan pembagian harta warisan masyarakat Aceh di Kecamatan Simpang Ulim dilakukan dengan dua cara yaitu pertama dengan murni secara hukum Islam, dan dengan cara kekeluargaan (adat). Alasan diberlakukannya sistem kekeluargaan karena mayoritas masyarakat tidak memahami hukum mewaris secara totalitas dalam Islam. Kedua, Penerapan hukum waris Islam terhadap pelaksanaan hukum waris pada masyarakat Aceh di Kecamatan Simpang Ulim adalah saling mengisi dan berdampingan dengan Hukum Adat. Pada kesempatan ini ahli waris akan meminta petunjuk pada tokoh agama secara mufakat kekeluargaan.

Keywords: Inheritance Law, Islamic Law, Customary Law, Simpang Ulim.

\section{Pendahuluan}

Menurut hukum adat tradisional di Aceh, segala harta warisan dibagibagikan sesuai Hukum Islam yang dibarengi oleh adat, tidak menurut hukum Islam semata-mata atau menurut adat semata-mata. ${ }^{1}$ Namun mayoritas masyarakat Aceh beranggapan bahwa pembagian secara hukum Islam yang dianggap paling benar, sehingga jika orang yang dianggap mengerti dan paham agama haruslah berdasarkan ketentuan faraid karena ini hukum Allah yang mengatur dan paling sempurna dibanding hukum lain karena itu hanya ketentuan dari manusia saja, yang belum tentu baik untuk kedepannya. ${ }^{2}$

Dalam masyarakat Aceh, pelaksanaan hukum waris dipengaruhi oleh hukum adat yang hidup di masyarakat, ahli warisnya sesuai dengan yang telah ditetapkan dalam hukum faraid, tetapi pada pembagian hartanya terkadang tidak mengikuti hukum faraid, tetapi sesuai kesepakatan bersama.

Pada dasarnya hukum adat beranggapan semua anak baik laki-laki maupun perempuan mempunyai hak atas peninggalan ibu dan bapaknya, artinya hak yang sama tidak memandang laki-laki atau perempuan dari harta peninggalan kedua orang tuanya dan membagi atau mempersamakan hak waris anak laki-laki dan anak perempuan yang didasarkan atas kesepakatan ahli waris, saling rela atau saling terima. Demikian halnya dalam hukum Islam bisa dimasukkan konsep as-Sulhu atau takharuj. As Sulhu adalah keikhlasan masing-masing pihak menerima kesepakatan yang disepakati

${ }^{1}$ Moehammad Hoesin, Adat Aceh (Banda Aceh: Dinas Pendidikan Kebudayaan Provinsi Daerah Istimewa Aceh, 1970).163

2http://kewarisanaceh,blogspot,co,id/2016/12/kewarisan-adat-aceh,html. Diakses tanggal 10 Agustus 2019. Pukul 12.28 WIB. 
dalam pembagian harta warisan. Dan takharuj diartikan keluarnya seorang atau lebih dari kumpulan ahli waris dengan penggantian haknya dari salah seorang diantara ahli waris lainnya". ${ }^{3}$

Penetapan kewarisan pada masyarakat Aceh di Kecamatan Simpang Ulim yang masyarakatnya mayoritas beragama Islam, dalam hal penanganan warisan lebih banyak tergantung kepada ahli warisnya, cara tersebut disebut dengan cara kekeluargaan, dan dapat berjalan dengan baik tanpa adanya konflik, misalnya para pihak bersepakat membagi jumlah harta ahli waris anak laki-laki sama besar dengan yang diberikan untuk anak perempuan. Hal itu bertentangan dengan yang diatur dalam Alquran Surat An-Nisa' ayat 11. Pelaksanaan penetapan tersebut dapat mengakibatkan terjadinya perselisihan/ sengketa waris dikarenakan ada ahli waris yang berpedoman pada hukum Islam dan ada yang berpedoman pada hukum adat.

Dalam penyelesaian sengketa waris pada masyarakat Aceh yaitu melalui musyawarah desa, ada yang namanya lembaga adat Aceh untuk menyelesaikan sengketa tersebut disamping ada pengadilan agama, yang dikenal dengan Mahkamah Syar'iyah. Lembaga adat biasanya ditingkat gampong seperti Keuchik, Imeum Meunasah atau perangkat Gampoemg lainnya. Kegiatan yang melibatkan perangkat Gampong ini juga diperkuat dengan adanya ketentuan yang mengatur pada Pasal 12 qanun Nomor 7 tahun 2000 tentang Penyelenggaraan Kehidupan Adat, bahwa, Keuchik dan Imeum Meunasah adalah pimpinan rapat adat gampong, dan memang biasanya masyarakat Aceh pun sebagian besar dalam menyelesaikan sengketa waris lebih menggunakan lembaga adat tersebut ketimbang Mahkamah Syar'iyah. ${ }^{4}$

Pada umumnya dalam kondisi damai pihak keluarga yang ingin menyelesaikan persoalan warisan melalui Gampong dan persoalan waris diselesaikan sesuai aturan-aturan agama Islam. Pembagian warisan boleh saja didasarkan pada keinginan ahli waris tetapi pada pertama pembagian tetap didasarkan dengan aturan hukum Islam. Jika sesudahnya ada pihak-pihak yang ingin membagi lagi haknya kepada ahli waris lainnya, hal itu akan diserahkan sepenuhnya kepada pihak keluarga. ${ }^{5}$

\section{Dasar Hukum Warisan Islam}

Kompilasi Hukum Islam pasal 171 ayat a, menyatakan bahwa hukum kewarisan adalah hukum yang mengatur tentang pemindahan hak pemilikan harta peninggalan (tirkah) pewaris, menentukan siapa-siapa yang berhak menjadi ahli waris dan berapa bagiannya masing-masing. ${ }^{6}$ Dalam kitab-kitab

${ }^{3}$ Amir Syarifuddin, Hukum Kewarisan Islam (Jakarta: Kencana, 2008).297

${ }^{4} \mathrm{http}: / /$ kewarisanaceh,blogspot,co,id/2016/12/kewarisan-adat-aceh,html. Diakses tanggal 10 Agustus 2019. Pukul 12.28 WIB.

5Wawancara dengan Alwi Bin Ibrahim, Mukim di Gampong Blang, 15 Nopember 2019.

6Tim Redaksi Nuansa Aulia, Kompilasi Hukum Islam (Bandung: Nuansa Aulia, 2012).81

Muhammad Nasir \& Khalidah | Penyelesaian Pembagian Warisan.....35 
fikih, warisan lebih sering disebut dengan Farâ'id mufradnya yang berarti ketentuan. Hal ini karena dalam Islam, bagian warisan yang menjadi hak ahli waris telah ditentukan dalam alqur'an. Menurut sejarah penggunaan kata Faraidh lebih dahulu dari pada mawaris. Rasulullah menggunakan kata Farâ'id dan tidak menggunakan kata mawaris.

Dalam hadis yang diriwayatkan oleh Ibnu Mas'ud disebutkan bahwa Rasulullah SAW bersabda;

"Pelajarilah al-Qur'an dan ajarkanlah kepada orang-orang. Dan pelajarilah ilmu faraid serta ajarkanlah kepada orang-orang, karena aku adalah orang yang akan direnggut (wafat), sedang ilmu itu akan diangkat dan fitnah akan tampak, sehingga dua orang yang bertengkar tentang pembagian warisan, mereka berdua tidak menemukan seorang pun yang sanggup meleraikan (menyelesaikan perselisihan pembagian hak waris) mereka." (HR. Ibnu Mas'ud) ${ }^{7}$

Menurut T.M Hasby Ash Shidiq, Ilmu mawaris adalah ilmu yang dengannya dapat diketahui tentang yang berhak dan yang tidak berhak untuk mendapatkan warisan, serta ketentuan yang berlaku bagi tiap ahli waris dan penyelesaian pembagiannya. ${ }^{8}$ Asy-Syarbini menulis definisi Fikih Mawaris ialah fikih yang berkaitan dengan pembagian warisan, pengetahuan tentang tata cara penghitungan yang dapat menyampaikan pada pembagian harta warisan dan pengetahuan-pengetahuan tentang bagian-bagian yang wajib dari harta peninggalan untuk setiap pemilik hak waris.

Berdasarkan definisi tersebut dapat ditarik kesimpulan bahwa pengertian kewarisan Islam adalah seperangkat aturan-aturan pemindahan hukum tentang pemindahan hak pemilikan harta peninggalan pewaris, mengatur kedudukan ahli waris yang berhak dan bagian masing-masing secara adil dan sempurna sesuai dengan ketentuan-ketentuan syari'at. ${ }^{9}$

Berdasarkan ayat dan hadist, prinsip-prinsip hukum kewarisan Islam adalah sebagai berikut: Pertama, hukum kewarisan Islam menempuh jalan tengah antara memberi kebebasan penuh kepada seseorang untuk memindahkan harta peninggalannya dengan jalan wasiat kepada orang yang dikehendaki, seperti yang berlaku dalam kapitalisme/individualisme, dan melarang sama sekali pembagian harta peninggalan seperti yang menjadi prinsip komunisme yang tidak mengakui hak milik perorangan, yang dengan sendirinya tidak mengenal sistem kewarisan. Kedua, warisan adalah ketetapan hukum, yang mewariskan tidak dapat menghalangi ahli waris dari haknya atas harta warisan,

\footnotetext{
${ }^{7}$ Abu Abdullah Muhammad bin Abdullah al-Hakim al-Naisaburi, Mustadrok 'ala shohihain, No. 8069 (Da'irah Al Ma'arif: tth).56

8T.M. Hasby Ash Shiddiqy, Fiqih Mawaris (Jakarta; Bulan Bintang, 1973).18

${ }^{9}$ Idris Djakfar dan Taufik Yahya, Kompilasi Hukum Kewarisan Islam (Jakarta: Pustaka Jaya, 1995).4
} 
dan ahli waris berhak atas harta warisan tanpa perlu kepada pernyataan menerima dengan sukarela atau atas keputusan hakim. Namun tidak berarti bahwa ahli waris dibebani melunasi hutang mayit (pewaris).

Ketiga, Warisan terbatas dalam lingkungan keluarga, dengan adanya hubungan perkawinan atau karena hubungan nasab/keturunan yang sah. Keluarga yang lebih dekat hubungannya dengan mayit (pewaris) lebih diutamakan daripada yang lebih jauh; yang lebih kuat hubungannya dengan mayit (pewaris) lebih diutamakan daripada yang lebih lemah. Misalnya, ayah lebih diutamakan daripada kakek, dan saudara kandung lebih diutamakan daripada saudara seayah. Keempat, hukum kewarisan Islam lebih cenderung untuk membagikan harta warisan kepada sebanyak mungkin ahli waris, dengan memberikan bagian tertentu kepada beberapa ahli waris. Misalnya, apabila ahli waris terdiri dari ayah, ibu, suami atau isteri, dan anak-anak, mereka semua berhak harta warisan.

Kelima, hukum kewarisan Islam tidak membedakan hak anak atas harta warisan. Anak yang sudah besar, yang masih kecil, yang baru saja lahir, semuanya berhak atas harta warisan orang tuanya. Namun, perbedaan besar kecilnya bagian diadakan sejalan dengan perbedaan besar kecil kewajiban yang harus ditunaikan dalam keluarga. Misalnya, anak laki-laki yang memikul beban tanggungan nafkah keluarga mempunyai hak yang lebih besar daripada anak perempuan yang tidak dibebani tanggungan nafkah keluarga.

Keenam, hukum kewarisan Islam membedakan besar kecilnya bagian tertentu ahli waris diselaraskan dengan kebutuhannya dalam hidup sehari-hari, disamping memandang jauh dekat hubungannya dengan mayit (pewaris). Bagian tertentu dari harta itu adalah 2/3,1/2, 1/3, 1/4, 1/6, dan 1/8. Ketentuan tersebut termasuk hal yang sifatnya ta'abbudi, yang wajib dilaksanakan karena telah menjadi ketentuan al-Qur'an. ${ }^{10}$

\section{Model Pembagian Harta Warisan di Kecamatan Simpang Ulim}

Pelaksanaan pembagian harta warisan yang berlaku pada masyarakat Aceh di Kecamatan Simpang Ulim dilakukan dengan dua cara yaitu pertama dengan murni secara hukum Islam, dimana Ahli waris dan bahagian yang diperoleh sesuai dengan ketentuan yang diatur dalam hukum waris Islam. Dan yang kedua menurut hasil dari musyawarah secara kekeluargaan dan kesepakatan para ahli waris, baik hanya melibatkan keluarga saja maupun dengan melibatkan perangkat desa.

Pelaksanaan hukum waris masyarakat Aceh yang berlaku di Kecamatan Simpang Ulim dilaksanakan menurut hasil dari musyawarah dan kesepakatan para ahli waris setelah pewaris meninggal dunia dan meninggalkan harta kekayaan baik yang bergerak ataupun yang tidak bergerak. Hukum adat tidak menetapkan sistem atau cara tertentu dalam hal pembagian harta warisan, pelaksanaannya dapat dilakukan secara tulisan atau secara lisan.

${ }^{10} \mathrm{Ahmad}$ Azhar Basyir, Hukum Waris Islam.10-13

Muhammad Nasir \& Khalidah | Penyelesaian Pembagian Warisan.....37 
Terkait waktu pembagian harta warisan, sebagaimana keterangan Tokoh Agama dan Tokoh Masyarakat 11 tidak ada kepastian, tergantung kesepakatan keluarga dan biasanya sesudah hari ke 100. Dalam hukum kewarisan adat dimasyarakat Aceh biasanya dilakukan pembagian harta-harta yang ditinggalkan oleh seorang yang telah meninggal dunia ialah pada hari-hari sesudah hari ke-44 atau ke-100 dari tanggal kematiannya sipewaris. Dengan demikian kendurikenduri (selamatan) yang diadakan untuk arwah dari seseorang yang meninggal dunia itu (keu arwah ureueng mate) sudah selesai diselenggarakan. ${ }^{12}$ Biaya-biaya kenduri (selamatan) tersebut merupakan dari harta si pewaris sebelum harta tersebut dibagikan kepada ahli waris.

Adapun mekanisme pembagian harta warisan yang lazim dilakukan dalam masyarakat Aceh di Kecamatan Simpang Ulim dilakukan setelah si pewaris meninggal dunia, namun didapati juga pada sebahagian keluarga yang melakukan pembahagian warisan sesuai dengan wasiat pewaris, hal ini dilakukan untuk mencegah terjadinya sengketa diantara ahli waris mengenai pembagian harta warisan.

Telah menjadi kebiasaan masyarakat Aceh di Kecamatan Simpang Ulim, pembagian harta warisan diawali dengan cara damai sesama ahli waris yang berhak menerimanya dan pelaksanaannya dipimpin oleh saudara tertua atau yang dianggap paling bijaksana. ${ }^{13}$ Jika dengan cara sesama ahli waris pembagian pusaka itu tidak berhasil dilaksanakan, maka dilaksanaan Pembagian Warisan ditingkat Gampong/Desa. Gampong adalah suatu wilayah yang ditempati oleh sejumlah penduduk sebagai kesatuan masyarakat yang terendah dan berhak menyelenggarakan rumah tangganya sendiri. ${ }^{14}$ Ahli waris mengundang tokoh-tokoh adat tersebut yaitu Keuchik (kepala desa), Imeum Meunasah (pemimpin keagamaan di gampong/ desa), ulama lokal dan Tuha Peut (tertua gampong/ desa) untuk dilakukan lagi secara damai serta dilaksanakan secara musyawarah dan mufakat. Apabila tidak tercapainya kesepakatan dan menimbulkan perselisihan ditingkat Gampong maka barulah diselesaikan melalui tingkat Mukim/ Persekutuan Desa.

Apabila menimbulkan sengketa atau perselisihan ditingkat gampong dan tidak dapat diterima atau tidak disepakati oleh salah satu pihak/ para pihak, maka dilakukan lagi dengan cara damai ditingkat Mukim. Mukim adalah kesatuan mayarakat hukum adat dalam propinsi daerah istimewa Aceh yang terdiri dari

\footnotetext{
11Wawancara dengan Alwi Bin Ibrahim (Mukim di Gampong Blang, tanggal 15 Nopember 2020), Fakhrurrazi (Pimpinan Dayah Babul Ma'arif di Peulalu, 23 Nopember 2020) dan Ismail (Pimpinan Dayah Babul Khairat di Gampong Matang Seupeng, 23 Nopember 2020). ${ }^{12}$ Moehammad Hoesin, Adat aceh.163

13Wawancara dengan Alwi Bin Ibrahim, Mukim di Gampong Blang, 15 Nopember 2019.

${ }^{14}$ Pasal 1 Angka 9 Peraturan Daerah Nomor 7 Tahun 2000 Tentang Penyelenggara Kehidupan Adat.
} 
beberapa Gampong yang mempunyai batas-batas wilayah tertentu dan harta kekayaan sendiri. ${ }^{15}$

Pelaksanaan warisan ditingkat Mukim dilakukan oleh Imeum Mukim (Kepala Pemerintahan Mukim/Persekutuan Desa), Imeum Chiek (Pemimpin Keagamaan Di Mukim/Persekutuan Desa, Tuha Peut Mukim (Tertua di Mukim/Persekutuan Desa) dan Ulama Lokal yang mencoba juga mendamaikan urusan pembagian harta warisan tersebut dengan cara musyawarah. Kehadiran orang- orang tersebut merupakan undangan dari ahli waris. ${ }^{16} \mathrm{Hal}$ ini senada dengan yang diperintahkan oleh Pasal 11 Peraturan Daerah (Qanun) No. 7 Tahun 2000 Tentang penyelenggaraan kehidupan adat.

Apabila Proses pelaksanaan pembagian warisan ditingkat Gampong (Desa) dan ditingkat Mukim (Persekutuan Desa) tidak dapat terselesaikan maka para pihak dapat mengajukan gugatan ke Mahkamah Syar'iyah. Dalam penyelesaian sengketa dilakukan secara berjenjang yaitu ditingkat Gampong (Desa), Tingkat Mukim (Persekutuan Desa) dan terakhir melalui Lembaga Mahkamah Syar'iyah. penyelesaian ditingkat Mukim merupakan upaya terakhir untuk mendapatkan keadilan dalam jurisdiksi adat. ${ }^{17}$

\section{Faktor Pelaksanaan Hukum Waris Secara Kekeluargaan}

a. Kurang Memahami Sistem Kewarisan Islam

Tingkat Pendidikan masyarakat Aceh di Kecamatan Simpang Ulim sudah berada diatas rata rata karena mayoritas penduduk berpendidikan tinggi dan bergelut di bidang pemerintahan, tetapi terkait dengan ilmu waris kebanyakan dari mereka tidak paham mengenai pembagian waris dalam Islam, mereka hanya mengetahui Hukum waris sebatas 2 : 1 bahagian anak laki laki dan anak perempuan. Hal ini sesuai dengan hasil yang Penulis temukan bahwa sebagian besar masyarakat mengetahui tentang warisan melalui perantara tokoh agama dan tokoh masyarakat sebagai orang yang dipercaya mengetahui tentang ilmu waris Islam. ${ }^{18}$

b. Kesepakatan Seluruh Ahli Waris

Kesepakatan dari seluruh ahli waris sering dilakukan dengan cara musyawarah kekeluargaan setelah mereka mengetahui bahagiannya. Bila dari musyawarah tersebut menghasilkan kesepakatan bahwa pembagian warisan dilakukan dengan cara pembagian sama rata antara laki-laki dan perempuan, maka hal ini dapat diterima. ${ }^{19}$ Tetapi bila kesepakatan tidak terjadi maka pembagian harta warisan dilakukan sesuai dengan Ketentuan dalam Hukum Islam. Tokoh

\footnotetext{
15Pasal 1 Angka 9.

16Wawancara dengan Alwi Bin Ibrahim, Mukim di Gampong Blang, 15 Nopember 2019.

${ }^{17}$ Majelis Adat Aceh, Pedoman Peradilan Adat Di Aceh (Untuk Peradilan Adat Yang Adil Dan Akuntabel, Banda Aceh, 2008).12

18Wawancara dengan Fakhrurrazi, Ismail, Alwi Ibrahim, Abdullah AR dan Syamsul Bahri.

${ }^{19}$ Wawancara dengan Ismail, Pimpinan Dayah Babul Khairat di Gampong Matang Seupeng, 23 Nopember 2019.
} 
Agama tidak memaksa pembagian warisan harus dilaksanakan sesuai ketentuan menurut hukum Islam.

c. Saling Ikhlas Dari Para Ahli Waris

Seluruh ahli waris sudah mengetahui bagian masing masing yang seharusnya diperoleh sesuai hukum waris Islam, kemudian mereka menyetujui pembagian warisan sesuai dengan hasil musyawarah didasarkan atas rasa saling rela atau saling terima bagian diantara ahli waris. Misalnya, mempersamakan bagian antara ahli waris laki-laki dan perempuan. Dalam masyarakat Aceh dikenal istilah " $t a ~ m e u$ jeut jeut" artinya adalah ikhlas sama ikhlas.

d. Menjaga Hubungan Kekeluargaan

Keharmonisan hubungan kekeluargaan di sini adalah adanya keinginan dari seluruh anggota keluarga untuk hidup dalam persatuan yang harmonis dan kompak. Hal ini berarti bahwa pembagian harta warisan itu jangan sampai menyebabkan mengurangi atau menghilangkan rasa persaudaraan diantara mereka. ${ }^{20}$

e. Faktor Merawat Orangtua

Dalam tradisi masyarakat Aceh, ahli waris perempuan lebih dominan dan paling banyak menghabiskan waktu merawat pewaris sampai akhir hayatnya. ${ }^{21}$ Dan dalam masyarakat Aceh di Kecamatan Simpang Ulim hal ini juga sering terjadi dan menjadi tanggung jawab dari ahli waris perempuan. Sehingga kepadanya diberikan hak yang sama dengan ahli waris laki laki.

\section{Pelaksanaan Hukum Waris Berdasarkan Hukum Islam}

Penerapan hukum Islam dalam pelaksanaan pembagian harta warisan masyarakat Aceh di Kecamatan Simpang Ulim adalah saling berdampingan dan saling mengisi dengan hukum adat. ${ }^{22}$ Kepada seluruh ahli waris baik melalui tokoh agama atau orang yang memimpin pelaksanaan pembagian harta warisan akan terlebih dahulu menyampaikan tentang bahagian yang seharusnya diperoleh ahli waris berdasarkan aturan dalam hukum Islam, kemudian pelaksanaan pembagiannya dikembalikan kepada keputusan ahli waris, apakah dilakukan secara bagi sama (kekeluargaan) atau murni secara hukum Islam.

Menurut Tgk. Fakhrurrazi, peran dan pengaruh tokoh agama dalam proses pembagian waris sangatlah besar, pada saat pembagian harta warisan dan dalam memberikan kesimpulan. Tokoh agama menyampaikan model pembagian warisan berdasarkan hukum Islam, penetapan ahli waris dan harta warisan yang ditinggalkan benar-benar berdasarkan hukum Islam, dimana hak bagian ahli waris harus sesuai dengan yang ditentukan dalam Al-Quran. Tetapi tokoh agama juga

\footnotetext{
20 Wawancara dengan Syamsul Bahri, di Pucok Alue Sa, 15 Nopember 2019.

21 Wawancara dengan Muhammad Asnaullah, di Gampong Blang, 15 Nopember 2019.

${ }^{22}$ Wawancara dengan Alwi Bin Ibrahim (Mukim di Gampong Blang, tanggal 15 Nopember 2020), Fakhrurrazi (Pimpinan Dayah Babul Ma'arif di Peulalu, 23 Nopember 2020) dan Ismail (Pimpinan Dayah Babul Khairat di Gampong Matang Seupeng, 23 Nopember 2020). 
memberikan kesempatan kepada ahli waris untuk memberikan pendapatpendapat lain terhadap pembagian warisan. Dan tidak menjadi persoalan jika diantara ahli waris tidak menerima pembagian warisan secara Islam maka dapat dilaksanakan secara adat yaitu dengan mempersamakan bagian antara laki-laki dan perempuan yaitu dengan bagian 1:1 setelah tercapainya musyawarah dan mufakat. Namun yang harus diingat, tokoh agama tetap menganjurkan pelaksanaan bagian ahli waris tetap harus dilaksanakan terlebih dahulu untuk memperjelas apa saja bagian yang di dapat oleh ahli waris yang sesuai hukum Islam, setelah itu jika para pihak memiliki kesepakatan lain setiap pemilik hak harus memberikannya dengan ikhlas agar tidak terjadi perselisihan. ${ }^{23}$

Dengan demikian hubungan antara hukum adat dan hukum Islam begitu tampak dalam pelaksanaan waris pada masyarakat Aceh di Kecamatan Simpang Ulim. Sepanjang hukum adat tersebut tidak bertentangan dengan hukum Islam maka hukum adat dapat dibenarkan penerapannya. ${ }^{24}$ Tetapi bila terdapat ahli waris yang menghendaki pembagian secara Hukum Islam maka pelaksanaan pembagian secara hukum Islam murni merupakan keharusan.

Penerapan hukum adat dan hukum Islam disesuaikan dengan keadaan dan kebutuhan masyarakat. Aturan hukum adat diberlakukan dengan sendirinya yang tidak bertentangan dengan hukum Islam. Khususnya dalam penetapan bagian ahli waris sebagaimana yang telah ditetapkan dalam Al-Quran harus dilaksanakan terlebih dahulu dan jika nantinya ada kesepakatan lain berdasarkan hukum adat, para pihak diperbolehkan untuk melaksanakannya dengan ikhlas. Hal yang sering terjadi kesepakatan pembagian sama tidak atas dasar kerelaan laki laki yang mempunyai hak lebih besar dari perempuan tetapi kesepakatan pembagian sama muncul dari keinginan ahli waris yang disegani atau yang dituakan.

\section{Analisis Teori Maqashid al-Syari'ah}

Dalam penelitian ini penulis hendak menggunakan teori Maqashid al-Syari'ah al-Ammah (umum/universal). Hal itu dikarenakan hukum kewarisan Islam lebih banyak terkait dengan teori-teori Maqashid Syari'ah universal. ${ }^{25}$ Dengan kerangka teoritik Maqashid al-Syari'ah al-Ammah itulah penulis hendak mengkaji sejauh mana sisi kemaslahatan yang dikandung dalam sistem pembagian waris di Kecamatan Simpang Ulim. Apakah praktek pembagian kewarisan yang dilakukan telah sesuai dengan tujuan syariat yaitu kemaslahatan, hal ini akan sangat mempengaruhi legalitas konsep kewarisan di Kecamatan Simpang Ulim.

Maqashid al-syari'ah merupakan salah satu konsep penting dalam kajian hukum Islam, dimana inti dari teori maqashid al-syari'ah adalah untuk mewujudkan kebaikan sekaligus menghindarkan keburukan atau menarik

\footnotetext{
23Wawancara dengan Fakhrurrazi, Pimpinan Dayah di Peulalu, 23 Nopember 2019.

${ }^{24}$ Moehammad Hoesin, Adat aceh.163

25 Totok Jumantoro \& Samsul Munir Amin, Kamus Istilah Ushul Fikih (Jakarta: Amzah, 2005).98
} 
manfaat dan menolak madharat. Dalam hal ini berdasarkan Al-Quran pelaksanaan hukum waris yang diatur dalam hukum Islam mengenai bagian anak laki-laki adalah dua bagian anak perempuan bersifat mutlak dan harus dilaksanakan demikian.

Bahagian perempuan yang ditentukan tersebut seimbang dengan kewajibannya. Sebab dalam Islam, kaum wanita pada dasarnya dibebaskan dari memikul tanggung jawab ekonomi keluarga. Jika seseorang menerima bagian waris tinggi, pemberian hak disesuaikan dengan tanggung jawab yang dipikulnya. $^{26}$ Dua bagian untuk anak laki-laki sama dengan satu bagian anak perempuan yang ditetapkan dalam syariat Islam bertujuan untuk mendapatkan keseimbangan. Anak laki-laki memiliki tanggung jawab yang lebih besar dalam kehidupan masyarakat dibandingkan anak perempuan seperti menafkahi dirinya, anak-anaknya, istrinya, dan kerabat yang berada di bawah tanggungannya. Sedangkan anak perempuan tidak demikian, segala belanja yang bersifat materil menjadi tanggung jawab lakilaki yang lebih dewasa.

Sesungguhnya agama Islam telah memuliakan hak perempuan, yaitu dengan memberinya bagian dalam kewarisan. Padahal, pada masa jahiliyah, perempuan tidak mendapatkan hak waris. Pada surat An-Nisa' ayat 13 dan 14, Allah SWT memberikan penghargaan kepada hamba yang taat pada hukum waris Islam dan mengancamnya dengan neraka bagi orang yang tidak menjalankan syari'at waris.

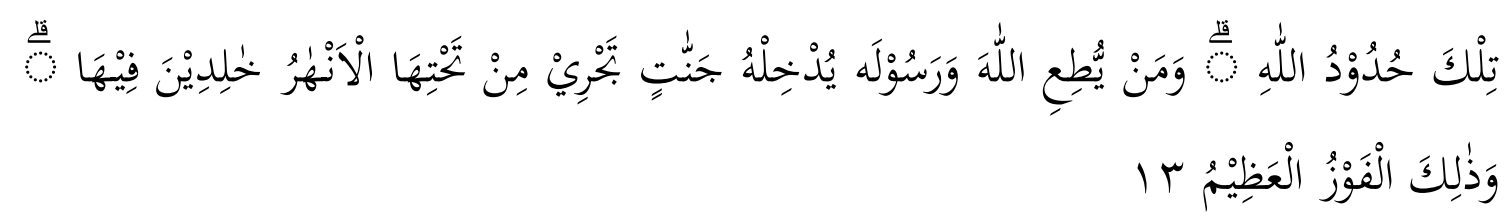

"Itulah batas-batas (hukum) Allah. Barangsiapa taat kepada Allah dan RasulNya, Dia akan memasukkannya ke dalam surga-surga yang mengalir di bawahnya sungai-sungai, mereka kekal di dalamnya. Dan itulah kemenangan yang agung." (QS. An-Nisa: 13)

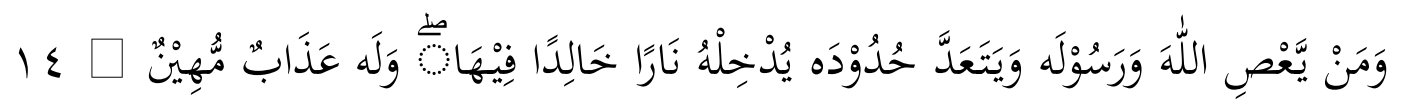

"Dan barangsiapa mendurhakai Allah dan Rasul-Nya dan melanggar batasbatas hukum-Nya, niscaya Allah memasukkannya ke dalam api neraka, dia kekal di dalamnya dan dia akan mendapat azab yang menghinakan." (QS. AnNisa: 14)

${ }^{26}$ Hasbi Umar, Nalar Fiqih Kontemporer (Jakarta: Gaung Persada Press, 2007).124 Muhammad Nasir \& Khalidah | Penyelesaian Pembagian Warisan.....42 
Harta waris yang diterima oleh anak laki-laki adalah 2 kali lipat dari perempuan, bagi orang yang tidak memahami rahasia hukum Islam tentu jumlah ini sangatlah merugikan kaum wanita. Tetapi jika mengacu kembali pada tujuan dari adanya hukum waris, yaitu keadilan, maka akan mengerti mengapa anak lakilaki mendapatkan bagian yang lebih besar. Keadilan bukan berarti memberi suatu hal yang sama besar, namun memberi sesuai dengan kebutuhan masing-masing.

Harta waris yang didapat anak laki-laki lebih besar, dengan maksud agar dipergunakan sebaik-baiknya untuk keluarganya kelak. Anak laki-laki mempunyai tanggungan terhadap anak dan istrinya, sehingga ia dapat menggunakan harta waris tersebut untuk memenuhi kebutuhan keluarganya. Berbeda dengan anak perempuan yang hanya mendapatkan harta waris setengah dari saudaranya, mereka memiliki hak pribadi terhadap harta mereka. Hukum ini juga berlaku untuk harta milik wanita dari hasil kerja jerih payahnya. Harta wanita adalah harta miliknya, di luar dari harta suami.

Islam telah mengatur secara jelas ketentuan tentang kewarisan untuk dipatuhi sebagaimana kita patuh dan taat dalam hukum sholat, puasa, dan lainnya, seorang Muslim wajib taat pada apa yang telah digariskan Allah SWT dan tidak ada satu orang pun yang boleh mengubah ketentuan Allah SWT atau melanggarnya, Allah SWT berfirman dengan nada ancaman terhadap orang yang melanggar ketentuan waris sebagaimana dalam Surat An Nisa ayat 14:

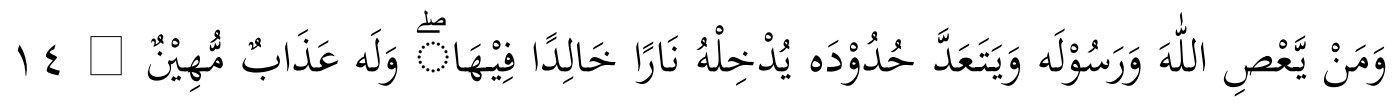

"Barang siapa yang menentang Allah dan Rasul-Nya dan melanggar ketentuan-ketentuan-Nya, Allah akan memasukkannya ke dalam neraka. Ia kekal di dalamnya dan ia berhak mendapatkan azab yang menghinakan." (QS An Nisa: 14).

Allah telah menyebutkan bahwa aturan tersebut adalah kewajiban yang harus dijalankan. Pembagian waris adalah kewajiban yang datangnya dari Allah. Dalam setiap ketentuan hukum syar'I terkandung kemaslahatan yaitu terciptanya kemaslahatan bagi manusia, bukan kemaslahatan yang timbul berdasarkan keinginan dan hawa nafsu manusia saja. Dipahami sepenuhnya bahwa tujuan pensyariatan hukum tidak lain adalah memberikan kemaslahatan bagi manusia dalam segala segi dan aspek kehidupan didunia dan di akhirat.

Maslahah ditinjau dari eksistensinya dalam hukum Islam terdiri dari tiga katagori yaitu maslaha mu'tabarah, maslahah mulghah dan maslahah mursalah. Maslahah mu'tabarah merupakan kemaslahatan yang ter-cover secara tekstual dalam nas. Atau kemaslahatan yang diakui validitasnya oleh Legislator dan 
terdapat dalil yang jelas untuk memlihara dan memproteksinya. ${ }^{27}$ Maslahah mulghah adalah kemaslahatan yang ditolak otoritas dan validitas oleh syara', karena bertentangan dengan ketentuan syara'. ${ }^{28}$ Maslalah mursalah adalah maslahah yang tidak didukung oleh sekumpulan makna nash (ayat atau hadis), bukan oleh nash yang rinci. ${ }^{29}$

Pembagian warisan secara kekeluargaan yang terjadi pada masyarakat Aceh di Kecamatan Simpang Ulim berada pada katagori maslahah mulghah yaitu maslahah yang tidak diakui atau tertolak oleh syara' karena bertentangan dengan ketentuan dalil yang jelas. Pembagian secara kekeluargaan dengan pembagian yang sama rata, bila tidak didasari oleh kerelaan secara langsung oleh yang memiliki hak, tertolak karena ada dalil yang menunjukkan bahwa bertentangan dengan ketentuan nash yang jelas dan qath'i. karenanya kepada tokoh agama dan tokoh adat sebagai pelaksana waris di masyarakat Aceh di Kecamatan Simpang Ulim hendaknya benar benar menerapkan hukum waris sebagaimana dalam nash.

Sebagaimana praktek pembagian sama rata antara laki laki dan perempuan dalam pembagian warisan, pada awal kelihatan ia memberikan kesamaan pembagian kepada laki laki dan perempuan, namun ia tidak diakui oleh syara' berdasarkan firman Allah Surah an-Nisa', ayat 11

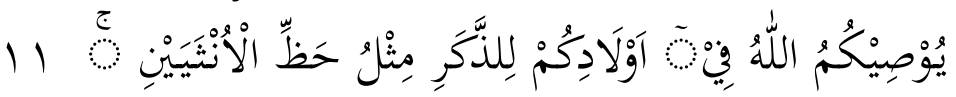

"Allah mensyariatkan (mewajibkan) kepadamu tentang (pembagian warisan untuk) anak-anakmu, (yaitu) bagian seorang anak laki-laki sama dengan bagian dua orang anak perempuan." (QS. An-Nisa: 11) ${ }^{30}$

Pada ayat di atas, Allah telah menetapkan bahwa dalam pembahagian harta pusaka, lelaki mestilah memperoleh bahagian yang lebih daripada perempuan dengan perbandingan 2:1. Oleh karenanya pembahagian secara sama rata antara lelaki dan perempuan adalah terbatal kecuali ahli waris laki laki setelah menerima haknya kemudian menyerahkan secara sukarela untuk dibagikan secara sama rata.

Nash menetapkan seorang laki-laki setara dengan dua anak perempuan. Oleh karena ingin menciptakan kemaslahatan, maka pembagiannya dirubah bahwa antara seorang anak laki-laki dengan seorang anak perempuan mendapat bagian sama dalam harta warisan. Penyamaan anak laki-laki dengan anak perempuan dengan alasan kemaslahatan inilah yang disebut dengan maslahat mulgah. penerapan hukum yang berdasarkan hawa nafsu tidak boleh dilakukan dan

\footnotetext{
${ }^{27}$ Muhammad al-Sâ'id 'Alî 'Abd al-Rabûh, Buhûs fi 'Adillah al-Mukhtalaf fîhâ 'inda Usûliyyîn (Mishr: Matba'ah al-Sa'âdah, 1980).95

${ }^{28}$ Nasroen Haroen, Usûl Fiqh (Jakarta: Logos Publishing House, 1996).119

${ }^{29}$ AbdulAzis Dahlan,Ensiklopedi Hukum Islam (Cet III; Jakarta : Ichtiar Baru Van Hoeve, 1999).146

${ }^{30}$ Kementerian Agama RI, Al-Qur'an dan terjemahnya.179-180
}

Muhammad Nasir \& Khalidah | Penyelesaian Pembagian Warisan.....44 
pembahagian yang demikian tidak boleh dilaksanakan. Terkecuali ahli waris laki laki telah mengambil haknya kemudian mengembalikan haknya untuk secara suka rela dibagi bersama demi menjaga keutuhan keluarga maka dapat dibenarkan, hal ini. Dalam surat Al-Imran ayat 103 Allah Swt. berfirman:

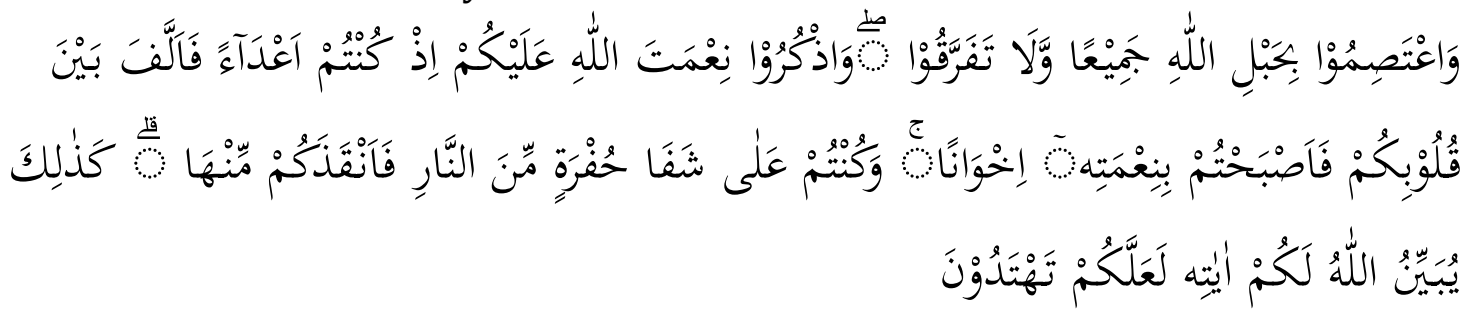

"Dan berpegang teguhlah kamu semuanya pada tali (agama) Allah, dan janganlah kamu bercerai berai, dan ingatlah nikmat Allah kepadamu ketika kamu dahulu (masa jahiliah) bermusuhan, lalu Allah mempersatukan hatimu, sehingga dengan karunia-Nya kamu menjadi bersaudara, sedangkan (ketika itu) kamu berada di tepi jurang neraka, lalu Allah menyelamatkan kamu dari sana. Demikianlah, Allah menerangkan ayat-ayat-Nya kepadamu agar kamu mendapat petunjuk." (QS. Ali-Imran: 103) ${ }^{31}$

Menurut analisis penulis yang mengkaji praktek pembagian warisan masyarakat Aceh di Kecamatan Simpang Ulim secara kekeluargaan, pembagian sama rata sebagaimana yang telah diterapkan tertolak oleh Syara'. Nash secara tegas telah menyebutkan pembagian harta warisan dimana bahagian seorang laki laki sama dengan dua bahagian anak perempuan. Pembagian secara kekeluargaan yang membagi sama rata, karena anggapan keberadaan anak laki laki dan anak perempuan sama kedudukannya dalam keluarga, dengan alasan ingin menciptakan kemaslahatan, maka pembagian yang demikian tidak dibenarkan.

Penetapan hak waris yang sama bagi anak laki-laki dan anak perempuan tidak memberikan keadilan bagi anak laki-laki yang memiliki tanggung jawab lebih besar. Terkecuali jika dilaksanakan terlebih dahulu pembagian yang sesuai syariat Islam, kemudian hak yang sudah diterima itu dikembalikan secara ikhlas untuk dilaksanakan pembagian secara kekeluargaan demi kemaslahatan.

Diantara maslahat yang dipelihara dalam Masyarakat Aceh di Kecamatan Simpang Ulim adalah terjaganya keutuhan keluarga pewaris dan terhindar dari perpecahan keluarga yang sangat dilarang oleh agama Islam. Banyak kasus keluarga yang tercerai berai dan terpecah ketika pembagian harta warisan dianggap tidak adil oleh anggota keluarga lainnya. Karena itu, pembagian warisan dengan memperhatikan semangat keadilan yang tumbuh dalam masyarakat dapat dibenarkan jika tidak bertentangan dengan hukum Islam. Dalam hal ini, pembagian harta warisan secara kekeluargaan dengan berdasarkan musyawarah mufakat

${ }^{31}$ Kementerian Agama RI, Al-Qur'an dan terjemahnya.200-201

Muhammad Nasir \& Khalidah | Penyelesaian Pembagian Warisan.....45 
dapat dibenarkan. Walaupun ketentuan bagian harta waris kepada laki-laki dua kali bagian perempuan adalah ketentuan yang sudah qath'i dan tidak dapat ditafsirkan lagi. Menangguhkan keberlakuannya demi alasan apapun itu tidak boleh dilakukan. Namun untuk menjaga keutuhan keluarga diperbolehkan setelah pelaksanaan penetapan hak waris sesuai yang diatur dalam hukum Islam.

Allah SWT menganjurkan manusia untuk bermusyawarah dalam memutuskan dan menetapkan segala hal dalam urusan duniawi. Firman Allah Swt dalam Surat Asy-Syura ayat 38 berfirman:

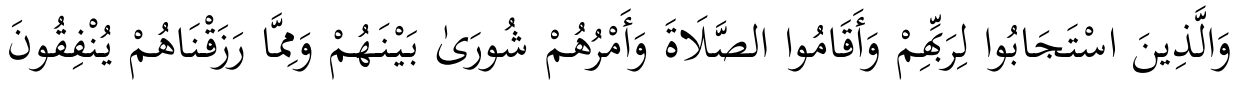

"Dan (bagi) orang-orang yang menerima (mematuhi) seruan Tuhannya dan mendirikan shalat, sedang urusan mereka (diputuskan) dengan musyawarah antara mereka dan mereka menafkahkan sebagian dari rezeki yang Kami berikan kepada mereka". (QS. Asy-Syura: 38)

Dari tinjauan hukum Islam terhadap pelaksanaan pembagian harta waris secara kekeluargaan pada masayarakat Aceh di Kecamatan Simpang Ulim maka dapat Penulis simpulkan bahwa pelaksanaan pembagian harta warisan dengan cara kekeluargaan adalah boleh dilakukan apabila kepada seluruh ahli waris telah disampaikan bahagian hak yang seharusnya diperoleh dan ahli waris laki laki telah mengetahui haknya kemudian secara suka rela melepas haknya untuk dibagikan secara bagi sama rata.

Inti dari maqashid syariah yang lima (ushul al-khams) dalam ketentuan kewarisan Islam dapat penulis jabarkan bahwa Memelihara agama dalam kewarisan Islam terwujud pada pentingnya umat Islam mempelajari hukum kewarisan Islam. dengan mempelajari hukum kewarisan adalah dalam rangka menjaga agama Islam itu sendiri. Memelihara agama (hifdz al-din) juga terwujud pada pelaksanaan segala ketentuan-ketentuan yang terdapat dalam hukum kewarisan Islam. Dengan mengikuti ketetapan Allah dalam masalah kewarisan, maka hal ini merupakan bukti ketundukan dan ketaatan seseorang terhadap hukum-hukum Allah. Memelihara jiwa dalam kewarisan Islam terwujud dari adanya ketentuan bahwa pembunuhan menghalangi untuk mendapatkan warisan.

Ketentuan ini menyiratkan adanya hubungan saling melindungi antara pewaris dengan ahli waris, sehingga wajar ketika yang melindungi memberikan harta kepada yang dilindungi, yaitu ahli warisnya. Namun demikian, jika hubungan ini dinodai dengan pembunuhan, maka konsekuensi logisnya juga tidak akan berlaku. Memelihara akal dalam kewarisan Islam terwujud pada pentingnya mempelajari hukum kewarisan Islam, sehingga diharapkan lahir ulama ulama yang berijtihad terhadap permasalahan baru muncul yang berkaitan dengan kewarisan Islam dan tidak terdapat jawabannya. Dengan berijtihad, maka itu adalah bentuk dari memelihara akal. Memelihara keturunan dalam kewarisan Islam terealisasi 
pada memelihara keutuhan dan kerukunan antara anggota keluarga. Dengan pembagian harta waris berdasarkan sistem kewarisan Islam, diharapkan masing masing ahli waris mendapatkan harta sesuai dengan porsinya sehingga tidak ada perpecahan dan persengketaan dalam keluarga. Memelihara harta terelaisasi pada pendistribusian harta waris yang sudah ditentukan oleh Allah porsi masingmasing ahli waris. Dengan sistem kewarisan Islam, diharapkan tidak ada monopoli dan penimbunan harta waris hanya pada seseorang saja. Harta waris dapat didistribusikan secara adil kepada ahli waris yang berhak menerimanya.

Mencermati hikmah dari pembagian warisan, maka maqashid syar'iyah pembagian waris lebih didominasi perlindungan terhadap keturunan (hifdz alnasl) dan harta (hifdz al-mal), dan menempati peringkat Hajiyyat. Dengan pembagian harta waris berdasarkan sistem kewarisan Islam, seluruh ahli waris mendapatkan harta warisan sesuai dengan porsinya, tidak ada monopoli dan penimbunan harta warisan pada seseorang saja, sehingga terhindar dari perpecahan dan persengketaan dalam keluarga. Ketentuan ini juga menunjukkan bahwa Islam tidak menghendaki adanya perampasan harta dan memakan harta orang lain.

Masalah kewarisan juga merupakan hak individu bagi setiap ahli waris, maka ketika ahli waris berdasarkan musyawarah kekeluargaan yang dilakukan sesuai ketentuan syara' tidak mendapat bahagian sebagaimana ditentukan dalam ilmu fara'id, dengan melepas haknya secara rela dibagi sama, maka karena keberadaannya justru dapat mendatangkan maslahat dan ketertiban kepada para ahli waris, hal ini dibenarkan dan sejalan dengan tujuan syariat (maqasid asysyariah) yaitu mengutamakan kemaslahatan dan menjauhkan dari kerusakan serta menghindarkan umat dari kesulitan dan mendatangkan kemudahan.

Walaupun pembagian harta waris secara kekeluargaan pada masyarakat Aceh di Kecamatan Simpang Ulim tidak ditemukan konflik namun jika suatu saat musyawarah keluarga tidak menghasilkan rasa adil diantara ahli waris dan menimbulkan konflik maka penyelesaian akhir adalah dilaksanakan sesuai dengan ketetapan sebagaimana ditetapkan dalam hukum Islam dan atau diselesaikan ke Mahkamah Syar'iyah.

Praktek yang terjadi pada Masyarakat Aceh di Kecamatan Simpang Ulim sangat dilatarbelakangi karena kurangnya pemahaman tentang Ilmu Faraidh dan menghindari biaya faraidh yang harus dikeluarkan jika dilakukan pembahagian melalui tokoh agama atau tokoh adat. Masyarakat memilih melakukan pembahagian secara kekeluargaan karena dianggap paling mudah, tidak rumit dan terhindar dari perpecahan keluarga.

\section{Penutup}

Mekanisme pelaksanaan pembagian harta warisan masyarakat Aceh di Kecamatan Simpang Ulim dilakukan dengan dua cara yaitu pertama dengan murni secara hukum Islam, dimana ahli waris dan bahagian yang diperoleh sesuai dengan 
ketentuan yang diatur dalam hukum waris Islam. Kedua menurut hasil dari musyawarah secara kekeluargaan dan kesepakatan para ahli waris, baik hanya melibatkan keluarga saja maupun dengan melibatkan perangkat desa. Praktek pembagian yang tidak seragam ini disebabkan karena adanya pandangan bahwa pembagian secara kekeluargaan dianggap paling mudah dan tidak rumit dalam pembagian.

Penerapan hukum waris Islam terhadap pelaksanaan hukum waris pada masyarakat Aceh di Kecamatan Simpang Ulim adalah saling mengisi dan berdampingan dengan Hukum Adat. kepada seluruh ahli waris baik melalui tokoh agama atau orang yang memimpin pelaksanaan pembagian harta warisan akan terlebih dahulu menyampaikan dan memperjelas bahagian yang diterima oleh ahli waris berdasarkan aturan dalam hukum Islam, kemudian jika ada kesepakatan berdasarkan hasil musyawarah keluarga para ahli waris diperbolehkan mengembalikan bagian hak warisnya untuk dilaksanakan pembagian dengan jumlah yang sama tanpa ada paksaan dan harus dilakukan secara ikhlas agar tidak terjadi perselisihan antara ahli waris.

\section{Daftar Pustaka}

AbdulAzis Dahlan,Ensiklopedi Hukum Islam. Jakarta: Ichtiar Baru Van Hoeve, 1999. Abu Abdullah Muhammad bin Abdullah al-Hakim al-Naisaburi, Mustadrok 'ala shohihain, No. 8069. Da'irah Al Ma'arif: tth.

Amir Syarifuddin, Hukum Kewarisan Islam. Jakarta: Kencana, 2008.

Alwi Bin Ibrahim , Wawancara Mukim Gampong Blang, Nopember, 15, 2019.

Fakhrurrazi, Wawancara Pimpinan Dayah Babul Ma'arif di Peulalu, Nopember, 26, 2020.

Hasbi Umar, Nalar Fiqih Kontemporer, (Jakarta: Gaung Persada Press, 2007.

Idris Djakfar dan Taufik Yahya, Kompilasi Hukum Kewarisan Islam. Jakarta: Pustaka Jaya, 1995.

Ismail, Wawancara Pimpinan Dayah Babul Khairat di Gampong Matang Seupeng, Nopember, 23, 2020.

Majelis Adat Aceh, Pedoman Peradilan Adat Di Aceh. Untuk Peradilan Adat Yang Adil Dan Akuntabel, Banda Aceh, 2008.

Moehammad Hoesin, Adat Aceh. Banda Aceh: Dinas Pendidikan Kebudayaan

Provinsi Daerah Istimewa Aceh, 1970.

Muhammad Asnaullah, Wawancara masyarakat di Gampong Blang, Nopember, 15, 2019.

Muhammad al-Sâ'id 'Alî 'Abd al-Rabûh, Buhûs fi 'Adillah al-Mukhtalaf fîhâ 'inda Usûliyyîn. Mishr: Matba'ah al-Sa'âdah, 1980.

Nasroen Haroen, Usûl Fiqh. Jakarta: Logos Publishing House, 1996. 
Syamsul Bahri, Wawancara Warga Simpang Ulim di Pucok Alue Sa, Nopember, 15, 2019.

Pasal 1 Angka 9 Peraturan Daerah Nomor 7 Tahun 2000 Tentang Penyelenggara Kehidupan Adat.

Tim Redaksi Nuansa Aulia, Kompilasi Hukum Islam. Bandung: Nuansa Aulia, 2012.

T.M. Hasby Ash Shiddiqy, Fiqih Mawaris. Jakarta; Bulan Bintang, 1973.

Totok Jumantoro \& Samsul Munir Amin, Kamus Istilah Ushul Fikih. Jakarta: Amzah, 2005. 